\title{
Sosyal Girişimcilik Becerilerinin Kazandırılmasında Bir Araç Olarak Yaratıcı Dramaya Yönelik Algılar ${ }^{\text {* }}$
}

\author{
Derya GIRGIN \\ Dr. Öğr. Üyesi, Çanakkale Onsekiz Mart Üniversitesi, \\ Eğitim Fakültesi, Özel Eğitim Bölümü \\ deryagirgin@comu.edu.tr \\ Orcid ID: https://orcid.org/0000-0002-6114-7925 \\ Nur AKCANCA \\ Dr. Öğr. Üyesi, Çanakkale Onsekiz Mart Üniversitesi, \\ Eğitim Fakültesi, Temel Eğitim Bölümü \\ nurakcanca@comu.edu.tr \\ Orcid ID: https://orcid.org/0000-0003-4074-0639
}

\begin{abstract}
Öz
Öğretmen adaylarının sosyal girişimcilik becerilerinin kazandırılmasında bir araç olarak yaratıcı dramaya ilişkin analojiler geliştirmeleri amaçlanan bu araştırmada nitel araştırma yöntemlerinden bütüncül tek durum deseni kullanılmıştır. Araştırmada elde edilen veriler, Temel Eğitim Bölümü'ne devam eden amaçlı örneklem yöntemiyle belirlenen 90 öğretmen adayından analoji geliştirme formu aracılığıyla toplanmıştır. Adayların geliştirmiş olduğu analojiler; kaynak kavram ve hedef kavram arasındaki ilişki, sunum şekli, soyutlanma düzeyi, zenginlik durumu bakımından sınıflandırılmıştır. Araştırmada güvenirliğin sağlanması için veriler arası karşılaştırma yapılmış, araştırmacılar arasındaki güvenirlik oranı $\% 88$ olarak tespit edilmiştir. Öğretmen adaylarının sosyal girişimcilik becerilerinin kazandırılmasında bir araç olarak yaratıcı drama kavramına yönelik geliştirdikleri analojilerin sınıflama biçimlerine göre tamamının sözel analojiler olduğu, basit analoji, yapısal analoji ve somut-soyut analojilerin sayıca fazla olduğu belirlenmiştir. Araştırmada öğretmen adaylarının sınırlı çeşitlilikte geliştirmiş oldukları analojiler
\end{abstract}

\footnotetext{
${ }^{1}$ Makale Geliş/Kabul Tarihi: 13.02.2020 / 11.04.2020

* Bu çalışma "Yaratıcı Drama Yöntemiyle Hazırlanan Etkinliklerin Temel Eğitim Bölümü Öğretmen Adaylarının Sosyal Girişimcilik Becerilerine Etkisi” isimli Çanakkale Onsekiz Mart Üniversitesi Bilimsel Araştırma Projeleri Koordinasyon Birimi Tarafından SBA-2019-3027 numaralı proje kapsamında desteklenerek gerçekleştirilmiştir.

Künye Bilgisi: Girgin, D. ve Akcanca, N. (2020). Sosyal Girişimcilik Becerilerinin Kazandırılmasında Bir Araç Olarak Yaratıcı Dramaya Yönelik Algılar. Kahramanmaraş Sütçü Imam Üniversitesi Sosyal Bilimler Dergisi, 17 (1), 45-63. DOI: $10.33437 / \mathrm{ksusbd} .688809$
} 
irdelendiğinde, soyut bir kavram olan sosyal girişimcilik kavramını aktif bir yöntem olan yaratıcı drama ile ilişkilendirme noktasında sorun yaşadıklarını, sosyal girişimciliğin çok boyutlu yapısını tam olarak kavrayamadıkları görülmektedir. Araştırma sonuçları çerçevesinde hizmet öncesinde öğretmen adaylarının sosyal girişimcilik konusunda donanımlı yetiştirilmesi için yaratıcı drama gibi etkileşimli tekniklerin kullanımının yaygınlaştırılması ve uygulamalı eğitimler ile farkındalık oluşturulması önerilmektedir.

Anahtar Kelimeler: Sosyal Girişimcilik, Yaratıcı Drama, Analoji, Öğretmen Adayları.

\title{
Perceptions of Creative Drama as a Tool for Teaching Social Entrepreneurship Skills
}

\begin{abstract}
This study aimed to develop analogies related to creative drama as a tool for teaching pre-service teachers' social entrepreneurship skills. A holistic single state pattern, one of the qualitative research methods, was used. 90 pre-service primary teachers participated to the current study determined by purposeful sampling method. The related data were collected were collected by analogy development form. The analogies developed by pre-service teachers were classified in terms of the relationship between the source concept and the target concept, presentation style, level of abstraction and content richness. Data analysis of researchers was compared, and the reliability rate of the researchers was determined as $88 \%$ in order to ensure reliability. Results indicated that the analogies developed by the pre-service teachers towards the concept of creative drama as a tool to gain social entrepreneurship skills were verbal analogies in terms of classification styles. In addition, it has been determined that simple analogy, structural analogy and concrete-abstract analogies were more numerous. When the analogies created by the pre-service teachers in a limited variety was examined, it was seen that they had problems in associating the concept of social entrepreneurship with creative drama, and they could not fully grasp the multidimensional structure of social entrepreneurship. It was also recommended to increase the use of interactive techniques such as creative drama and raise awareness through applied trainings in order to train pre-service teachers equipped with social entrepreneurship.
\end{abstract}

Keywords: Social Entrepreneurship, Creative Drama, Analogy, Pre-Service Teachers. 


\section{GİRIŞ}

Günümüzde değişen yaşam şartlarına uyum noktasında kazandırılması gereken temel yaşam becerileri arasında sosyal girişimcilik kavramı yerini almıştır. İçerisinde çok yönlü yapılar barındırması nedeniyle sosyal girişimciliğin net bir tanımına rastlamak güçtür. Genel olarak bakıldığında ise, sosyallik ve girişimcilik kavramlarını içeren sosyal girişimcilik, toplum sorunlarını dönemin şartlarına uygun olarak girişimci bir yapıyla ele almayı ve farklı stratejiler üreterek çözüm üretebilmeyi ifade etmektedir (Eraslan, 2011; Katzenstein ve Chrispin, 2011; Kümbül Güler, 2008).

Sosyal girişimcilik, toplumsal fayda sağlayarak sosyal değer oluşturmayı amaçlar (Besler, 2010; Gusseinova, 2015; Kickul ve Lyons, 2012; Konaklı ve Gögüss, 2013). Bu sosyal değer oluşturma sürecinde aktif rol oynayan bireyler, sosyal girişimci bireyler olarak tanımlanmaktadır (Biçer ve Başer, 2019). Sosyal girişimci bireyler risk alabilmeleri, hızlı karar verebilmeleri, yaratıcı, yenilikçi olmaları, kendilerine olan güvenleri ve başarılı olma güdüleri gibi karakteristik özelliklere sahiptir (Akpınar, 2009).

Toplumlarda çok önemli bir rol üstlenen öğretmenlik mesleği sosyal girişimcilik becerilerinin kazandırılmasında diğer meslek gruplarına göre daha çok öne çıkmaktadır. Çünkü öğretmenlik mesleği etki alanındaki tüm paydaşlarıyla güçlü bir etkileşim içerisinde bulunarak, bireylere rol model olma ve onları yönlendirme noktasında belirgin özelliklere sahiptir (Çermik ve Şahin, 2015).

Öğretmenlik mesleği genel yeterlilikleri incelendiğinde (Milli Eğitim Bakanlığ [MEB], 2017), öğretmenlerin hem mesleki bilgi, beceri hem de tutum ve değerler noktasında sosyal girişimcilik becerilerine ihtiyaç duydukları görülmektedir (Öztürk vd., 2019). Dolayısıyla öğretmenlerin mesleki bilgi ve becerileri kazandıkları hizmet öncesi dönem, sosyal girişimcilik kavramının eğitsel bir bakış açısıyla doğru yapılandırılması noktasında önem kazanmaktadır (Deveci, 2018; Ikävalko vd., 2009). Yüksek Öğretim Kurumu tarafindan son güncellenen öğretmenlik lisans programlarında 'Ekonomi ve Girişimcilik' ismiyle yer alan seçmeli dersin içeriğine bakıldığında (YÖK, 2018), girişimciliğin ekonomik boyutunu ele alınarak, kültürel ve sosyal boyutunun göz ardı edildiği görülmektedir. Fakat girişimcilik kültürünün oluşturulması ve girişimcilik sürecinin etkin olarak yapılandırılması için girişimciliği oluşturan toplumsal, sosyal, kültürel ve ekonomik boyutların eş güdümlü olarak ele alınması gerekmektedir. Tüm bu boyutların bir arada ele alınması, sosyal girişimcilik becerileri gelişmiş öğretmenler yetişmesine olanak sağlayacaktır. Sosyal girişimcilik becerileri gelişmiş bu öğretmenler ise meslek yaşantılarında sosyal girişimciliğin doğasına uygun bir öğrenme ortamı oluşturabilecek, öğretim 
süreçlerinde aktif ve doğru yönlendirmeler sayesinde yeni imkanların farkında olabilecek öğrenciler yetiştirip, toplumda sosyal girişimci sayısını arttıracaktır (Çalışkan, 2019; Eraslan, 2011; Karademir vd., 2018). Bu bağlamda tüm eğitim kademelerinde işlevsel olarak sosyal girişimcilik becerilerini kazanmış bireyler karşımıza çıkacaktır (Armut ve Kılınç, 2018).

Toplumda sosyal girişimci bireylerin artması, öğretmenlerin sosyal girişimci bireylerin teoriye bağlı olarak değil deneyim ve yaşantılara bağlı olarak öğrenmelerini dikkate alma çabalarıyla yakından ilgilidir (Bornstein ve Davis, 2010). Bu yaşantıların deneyimlenebileceği, yaşamın küçük bir provası olarak da nitelendirilen yaratıcı drama öğrencilerin yaşadıkları dünyaya bakış açıları ve karşılaşacakları problem durumları ile başa çıkma firsatı sunması yönüyle ön plana çıkmaktadır (Bal İncebacak vd., 2017).

Yaratıcı drama kurgu yoluyla gerçekliğe bakmaları için bireylere olanak tanıyarak, bireylerin eylemleri derinlemesine anlamlandırmasını sağlar. $\mathrm{Bu}$ noktada yaratıcı drama sosyal, duygusal ve toplumsal öğeleri bir arada ele alan aktif bir yöntem olarak kullanılmaktadır (McCaslin, 2016; Önder, 2003). Yaratıcı dramaya öğretim süreçlerinde yer verilmesinin en önemli sebebi öğrencilerin bağımsız düşünebilmeleri, grup içinde iş birliği yaparak kendi düşüncelerini geliştirmeleri ve onlara farklı çevrelerde sosyal farkındalık geliştirmeleri için olanak sunmasıdır (McCaslin, 2016). Yaratıcı drama bireylere kazandırdığı özellik ve beceriler anlamında değerlendirildiğinde, sosyal girişimcilik eğitiminin de kazandırmayı amaçladığı becerilerin önemli ölçüde benzerlik gösterdiği görülmektedir (Zibeniene ve Virbaliene, 2014). Sosyal girişimcilik kavramı ile yaratıcı dramanın bireyde kazandırmayı amaçladığı bu ortak beceriler alan yazın incelenerek (Akpınar, 2009, McCaslin, 2016; Oğuz, 2019; Özdevecioğlu ve Cingöz, 2009; Paksoy vd., 2019) araştırmacılar tarafindan oluşturulmuş ve Şekil 1'de gösterilmiştir.

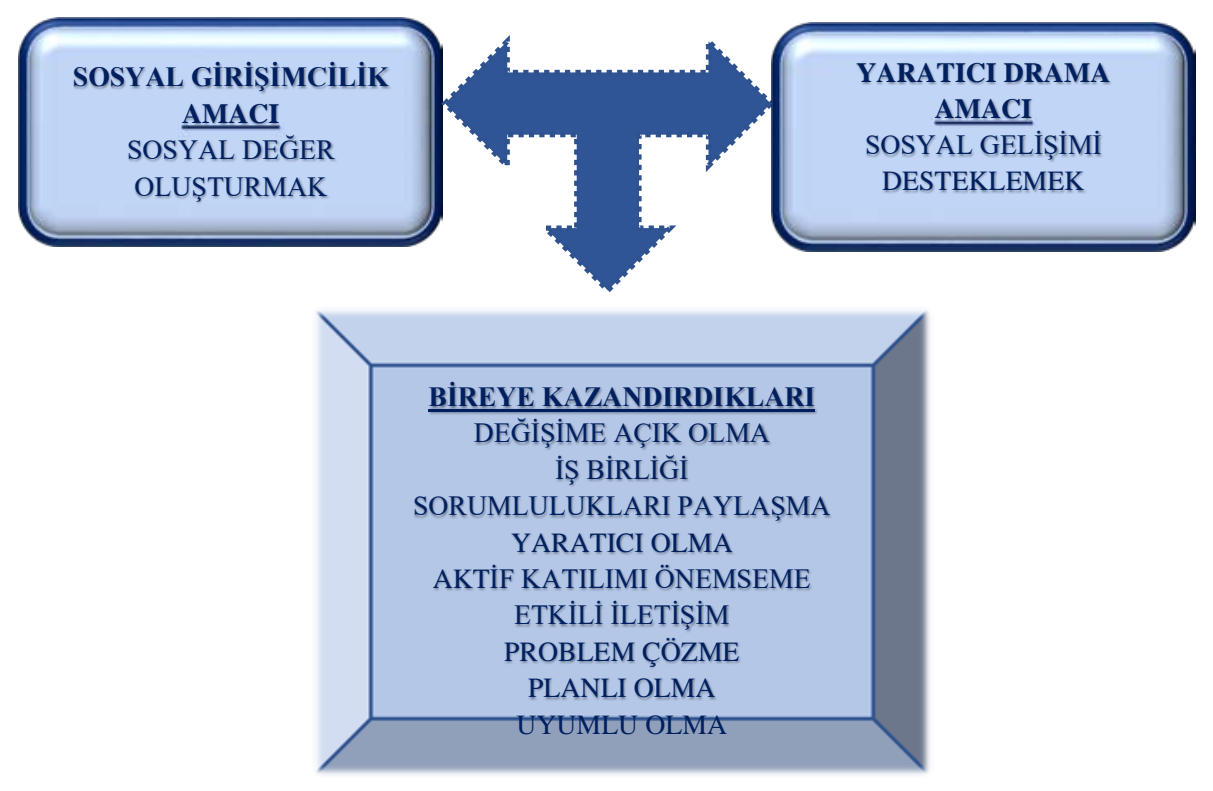


Şekil 1. Sosyal Girişimcilik Kavramı ile Yaratıcı Dramanın Bireyde Kazandırmayı Amaçladıkları Ortak Beceriler

Şekil 1 incelendiğinde sosyal girişimciliğin genel amacının sosyal değer oluşturmak iken; yaratıcı drama da genel amaç sosyal gelişimin desteklenmesi olarak karşımıza çıkmaktadır. Her iki kavramın genel amaçlarına bakıldığında sosyal olgulara odaklanıldığı anlaşılmaktadır. Toplumsal yaşama uyum noktasında sosyal olgular bireyler için temel oluşturmaktadır. Bu bağlamda sosyal girişimcilik ile yaratıcı dramanın bireyde kazandırmayı amaçladıkları ortak beceriler sosyal beceriler olarak ortaya çıkmaktadır. Bu beceriler; değişime açı olma, iş birliği içinde sorumlulukları paylaşma, yaratıcı olup aktif katılımı önemseme, etkili iletişim becerilerine sahip olma, problem çözme, hızlı karar verme, planlı ve uyumlu olmadır. Bu noktada araştırmada bu iki kavramın bireylerin zihinlerindeki yerinin belirlenmesi, bireylere kazandirılması amaçlanan beceriler açısından önemli olduğu düşünülmektedir.

Sosyal girişimcilik gibi kavramların öğretiminde bireylerin eleştirel ve yenilikçi bakış açısını ortaya çıkaran yöntemlerden biri de analojilerdir. Analojiler, bilinmeyen bir durum (hedef kavram) ile bilinen bir durum arasinda (kaynak kavram) ilişkisel bağ kurarak, bireylerin eski bilgileri ile yeni bilgileri arasında köprü görevinde önemli bir rol oynamaktadır (Yerrick vd., 2003). Gerçek benzerlikten farklı olarak analojilerde, durumun hangi özelliğine odaklanılıyorsa o özelliklerdeki benzerliğin incelenmesi esastır (Güler, 2014). Bu bağlamda bilgilerin zihinde kalıcılığını arttıran bir yöntem olarak analojiler kullanılmaktadır (Kadayıfçı, 2008). Bununla birlikte analojiler, olayları farklı değerlendirip üst düzey düşünebilmelerine, sebep-sonuç ilişkilerini doğru şekilde kurup, günlük hayatta karşılaşılan kavramların anlamlı şekilde öğrenilmesine katk1 sağlar (Yenice, Alpak Tunç ve Yavaşoğlu, 2018). Analojilerle ilgili alan yazın incelendiğinde, araştırmaların genellikle ders kitaplarındaki analojilerin tespitine yönelik olduğu görülmektedir (Demirci Güler ve Yağbasan, 2008; Karadeniz, 2017; Kaya, 2010; Newton, 2003; Schreglmann, 2019). Ders kitaplarında hazır olarak öğrenciye sunulan analojilerden ziyade öğrencilere kendi analojilerini hazırlama firsatı verilmesi ile öğrenme süreci daha aktif hale gelip, anlamlı öğrenmeler gerçekleşecektir (Akar, 2007; Atav vd., 2004; Yerrick vd., 2003). Bu sebeple araştırmada öğretmen adaylarının sosyal girişimcilik kavramının sadece teorik olarak tanımını yapmaları değil, bu kavramı zihinlerinde kavramlar arası ilişkilerle doğru yapılandırmaları için sosyal girişimcilik becerilerinin kazandırılmasında bir araç olarak yaratıcı dramaya ilişkin analojiler geliştirmeleri amaçlanmıştır. 


\section{YÖNTEM}

\section{Araștırma Modeli}

$\mathrm{Bu}$ araştırmada nitel araştırma yöntemlerinden bütüncül tek durum deseni kullanılmıştır. Bütüncül durum çalışmaları bütüncül bakış açısı ile daha önce üzerinde çalışılmamış durumların irdelenmesine imkân tanımaktadır (Best ve Kahn, 2017; McMillan ve Schumacher, 2014; Merriam, 2013; Stake, 2003). Durum çalışmalarının en önemli özelliği, güncel bir olgunun gerçek bağlamda araştırılmasıdır (Yin, 2003). Bütüncül tek durum deseninde araştırmaya konu olan bir birey, bir kurum ya da bir program yani tek bir analiz birimi yer almaktadır (Yıldırım ve Şimşek, 2011). Yapılan araştırmadaki analiz birimini Çanakkale Onsekiz Mart Üniversitesi Eğitim Fakültesi Temel Eğitim Bölümü oluşturmaktadır. Araştırmada öğretmen adaylarının sosyal girişimcilik becerilerinin kazandırılmasında bir araç olarak yaratıcı dramayı tanımlamaları açısından her durumun kendi içinde bütüncül olarak ele alınıp karşılaştırıldığı bütüncül tek durum deseni kullanılmıştır.

\section{Çalışma Grubu}

Araştırmanın çalışma grubunu, 2019-2020 Eğitim-Öğretim yılında Çanakkale Onsekiz Mart Üniversitesi Temel Eğitim Bölümüne devam eden 90 (34 erkek, 56 kız) öğretmen adayı oluşturmaktadır. Söz konusu çalışma 21-25 Ekim 2019 tarih aralığında gerçekleştirilmiştir. Araştırmanın örneklemi amaçlı örnekleme yoluyla belirlenmiştir. Amaçlı örneklem, çalışmanın amacına uygun ayrıntılı araştırma yapabilmek için bilgi açısından zengin durumların belirlenmesi olarak tanımlanabilir (Neuman ve Robson, 2014; Yıldırım ve Şimşek, 2011). Öğretmen adaylarının lisans dersleri kapsamında 'Eğitimde Drama' ile 'Ekonomi ve Girişimcilik' derslerini almaları ve bu alanlarda nasıl benzetmeler yapacakları, benzetme yapılarının ve türlerinin nasıl olacağı, amaçlı örneklemin seçiminde belirleyici olmuştur.

\section{Veri Toplama Aracı}

Araştırmada öğretmen adaylarının sosyal girişimcilik becerilerinin kazandırılmasında bir araç olarak yaratıcı dramaya ilişkin analojileri belirlemek için araştırmacılar tarafından oluşturulan analoji geliştirme formu kullanılmıştır. Analoji geliştirme formunun hazırlanma aşamasında öncelikle alan yazın araştırmas1 yapılmıştır. Daha sonra uzman görüşleri ışığında gerekli düzeltmeler yapılarak forma son hali verilmiştir. Analoji geliştirme formunda Nottis ve McFarland (2001) bakış açısı merkeze alınarak, öğretmen adaylarının yalnızca bir tane analoji geliştirmeleri istenmiştir. Öğretmen adaylarından form üzerinde yer alan hedef kavram (bilinmeyen) ve kaynak kavram (bilinen) belirtilen 
alanlara yazması, bu kavramlar arasında var olan benzerliklerin ve farklılıkların listelenmesi istenmiştir.

\section{Verilen Toplanması}

Öğretmen adaylarının sürece katılımda gönüllü olmaları esasında; bilgilendirilme yapılıp süreç başlatılmıştır. Öğretmen adaylarına öncelikle analoji kavramı açıklanmıştır. Öğretmen adaylarının geliştirecekleri analojilerin içeriğini, yapısını ve çeşitlerini etkilememek amacıyla farklı konulardan analoji örnekleri verilmiştir. Öğretmen adaylarının kendi analojilerini yazmaları için ihtiyaç duydukları süre verilmiştir. $\mathrm{Bu}$ araştırmanın temel verileri öğretmen adaylarının kendi el yazıları ile yazıp geliştirdiği analojilerdir.

\section{Verilerin Analizi}

Öğretmen adaylarının geliştirmiş olduğu analojiler iki kez okunarak gözden geçirilmiş, boş bırakılan kağıtlar araştırma kapsamı dışında tutulmuştur. Böylece araştırmada 90 öğretmen adayının geliştirdiği 87 analoji sınıflandırılmıştır. Araştırma etiği açısından araştırmaya katılan Öğretmen adaylarının isimleri gizli tutularak $\mathrm{Ö}_{1}, \mathrm{OA}_{2}, \mathrm{Ö}_{3}, \ldots . . . \mathrm{Ö}_{87}$ şeklinde kodlar verilmiştir.

Araştırmada toplanan verilerin kavramsallaştırılması, belli özelliklere göre sınıflandırılması ve analoji türlerinin belirlenmesi gerekmektedir. Bu çerçevede analoji siniflandırmalarından Thiele ve Treagust (1994) tarafindan yapılan sınıflandırmanın araştırma yapısına uygun olan kısımları esas alınarak araştırma verileri sınıflandırılmıştır. Öğretmen adaylarının geliştirdikleri analojiler yapı ve çeşitlerine göre incelenerek, geliştirilen analojilere ilişkin farklı katılımcıların doğrudan alıntılarına yer verilerek bulgular yorumlanmıştır. Öğretmen adaylarının geliştirdiği analoji sınıflandırması için kullanılan ölçütler tablosu Tablo 1'de verilmiştir.

Tablo 1. Analoji Sınıflandırılması İçin Kullanılan Ölçütler

\begin{tabular}{ll}
\hline Kategori & Analoji türleri \\
\hline \multirow{2}{*}{ Kaynak ve Hedef Arasındaki Analojik İlişki } & Fonksiyonel \\
& Yapısal \\
& Yapısal- Fonksiyonel \\
\hline \multirow{2}{*}{ Sunum Şekli } & Sözel \\
& Resimsel \\
& Resimsel- Sözel \\
\hline \multirow{2}{*}{ Kaynak ve Hedefin Soyutlanma Düzeyi } & Somut- Somut \\
& Somut- Soyut \\
& Soyut- Soyut \\
\hline
\end{tabular}




\begin{tabular}{ll}
\hline Analojinin Zenginlik Durumu & Basit \\
& Zenginleştirilmiş \\
& Genişletilmiş \\
\hline
\end{tabular}

Tablo 1'de görüldüğü üzere araştırma verileri olan analojiler; kaynak kavram ve hedef kavram arasındaki ilişki, sunum şekli, soyutlanma düzeyi, zenginlik durumu bakımından sınıflandırılmıştır.

Alan yazında nitel araştırmaların geçerlik ve güvenirlik konusunun sağlanmasında inandırıcılık, aktarılabilirlik ve doğrulanabilirlik ölçütlerine vurgu yapılmaktadır (Lincoln ve Guba, 2000; Merriam ve Tisdell, 2015). Bu bağlamda bulgular kısmında verilerin sunumunda aktarılabilirlik ölçütü için öğretmen adaylarının doğrudan alıntılarına yer verilerek; farklı bakış açılarını yansıtılması ile çarpıcılık ölçütü, temalara uygunluk bakımından açıklayıcılık ölçütü, uç noktada yer alan örneklerin sunulması ile de çeşitlilik ölçütleri gerçekleştirilmeye çalışı1mıştır (Ünver vd., 2010). Araştırmada güvenirliği sağlamak amacıyla elde edilen veriler araştırmacılar tarafından incelenerek, veriler arası karşılaştırma yapılmıştır. Araştırmada elde edilen verilerin güvenirliğinin sağlanması için Miles ve Huberman'ın (2015) Görüş Birliği / (Görüş Birliği + Görüş Ayrıllı̆̆ x 100 formülü kullanılmıştır. Araştırmacılar arasındaki güvenirlik oranı \%88 olarak tespit edilmiştir.

\section{BULGULAR}

Araştırmanın amacına uygun olarak yapılan analizler sonucunda öğretmen adaylarının sosyal girişimcilik becerilerinin kazandırılmasında bir araç olarak yaratıcı dramaya ilişkin algılarının belirlenmesi amacıyla geliştirdikleri analojiler Tablo 2'de verilmiştir. 
Tablo 2. Öğretmen Adaylarının Sosyal Girişimcilik Becerilerinin Kazandırılmasında Bir Araç Olarak Yaratıcı Dramaya İlişkin Geliştirdikleri Analojiler

\begin{tabular}{llllll}
\hline Analoji adı & f & Analoji adı & f & Analoji adı & f \\
\hline Abaküs & 1 & Gözlemcilik & 1 & Oyun & 3 \\
Ağaç & 2 & Gözlük & 3 & Öğretmenlik & 1 \\
Antrenman & 1 & Yansıma & 1 & Ön Hazırlık & 1 \\
Araba Motoru & 1 & Hayat & 4 & Özel Ders & 1 \\
Ayna & 1 & Hedefe Yönelme & 1 & Özgürlük & 1 \\
Baba & 1 & Isınma & 1 & Peynir & 1 \\
Balon & 1 & İletişim & 1 & Rahatlık & 1 \\
Bisiklet Sürme & 1 & İp & 1 & Rehber & 2 \\
Boks Eldiveni & 1 & İp Düğümü & 3 & Sanat & 3 \\
Giyme & 1 & İş birliği & 2 & Serap & 1 \\
Büyüteç & 1 & İşlevsel & 1 & Silah & 1 \\
Ceviz Kıracağı & 1 & Kazma/Kürek & 1 & Simülasyon & 2 \\
Çay ve Şeker & 1 & Köprü & 6 & Tarak & 1 \\
Damar & 1 & Kutsal Bir Kâse & 1 & Tren & 1 \\
Deniz Feneri & 1 & Lunapark & 1 & Tuğla & 1 \\
Ders & 1 & Makine Parçası & 1 & Uçmak & 1 \\
Doğaçlama Metodu & 1 & Masa & 1 & Uyum & 1 \\
Dönme Dolap & 1 & Maskeli Baloya & 1 & Yapı Taşı & 2 \\
Eğitici Kitap & 1 & Matkap & 1 & Yemekteki Tuz & 1 \\
Elektrik Teli & 2 & Mikrofon & 1 & Yiyecek & 3 \\
Elektrikli Fırın & 2 & Okul & 2 & Yürüteç & 1 \\
\hline & & & & Toplam & 87 \\
\hline
\end{tabular}

Tablo 2'de görüldüğü gibi sosyal girişimcilik becerilerinin kazandırılmasında bir araç olarak yaratıcı drama kavramını öğretmen adaylarından 6'sı köprüye, 4'ü hayata, 3'ü gözlüğe, ip düğümüne, oyuna, sanata ve yiyeceğe, 2'si ağaca, elektrikli fırına, iş birliğine, okula, rehbere, simülasyona ve yapı taşına benzetmiştir.

Araştırmada öğretmen adaylarının sosyal girişimcilik becerilerinin kazandırılmasında bir araç olarak yaratıcı dramaya yönelik geliştirdikleri analojiler; ilişkilerine göre, sunum formatına göre, durumuna göre, zenginlik düzeyine göre analoji sınıflandırmalarına göre Tablo 3'te sunulmuştur. 
Tablo 3. Öğretmen Adaylarının Sosyal Girişimcilik Becerilerinin Kazandırılmasında Bir Araç Olarak Yaratıcı Dramaya İlişkin Analoji Sinıflandirmaları

\begin{tabular}{|c|c|c|}
\hline Kategori & Analoji türleri & f \\
\hline \multirow{3}{*}{$\begin{array}{l}\text { Kaynak ve hedef arasındaki analojik } \\
\text { ilişki }\end{array}$} & Yapısal & 7 \\
\hline & Fonksiyonel & 5 \\
\hline & Yapısal- Fonksiyonel & 3 \\
\hline \multirow[t]{3}{*}{ Sunum Şekli } & Sözel & 87 \\
\hline & Resimsel & - \\
\hline & Resimsel- Sözel & - \\
\hline \multirow{3}{*}{ Kaynak ve Hedefin Soyutlanma Düzeyi } & Somut- Somut & - \\
\hline & Somut- Soyut & 12 \\
\hline & Soyut- Soyut & 5 \\
\hline \multirow{3}{*}{ Analojinin Zenginlik Durumu } & Basit & 6 \\
\hline & Zenginleștirilmiş & 4 \\
\hline & Genisletilmis & 3 \\
\hline
\end{tabular}

Tablo 3'te görüldügüü üzere araştırma verileri olan analojiler; kaynak kavram ve hedef kavram arasındaki ilişki bakımından, sunum şekli bakımından, soyutlanma düzeyi bakımından, zenginlik durumu bakımından sınıflandırılmış, Öğretmen adaylarının geliştirdikleri analojilerle, bunların yapı ve çeşitlerine göre frekans (f) değerleri verilmiştir.

Tablo 3'te öğretmen adayları sosyal girişimcilik becerilerinin kazandırılmasında bir araç olarak yaratıcı drama kavramına ilişki düzeylerine göre 7 yapısal analoji, 5 fonksiyonel analoji ve 3 yapısal ve fonksiyonel analoji geliştirmiştir. Yapısal analojiler, kaynak ve hedef kavramın şekil, görünüş ve büyüklük gibi özellikleri yönünden; fonksiyonel analojiler kaynak ve hedef kavram görev, hareket ve davranış gibi özellikleri yönünden ele alınmaktadır. Yapısal ve fonksiyonel analojiler ise hem şekil, görünüş ve büyüklük hem de görev, hareket ve davranış gibi özellikler yönünden ele alınmaktadır. Araştırmada öğretmen adayları sosyal girişimcilik becerilerinin kazandırılmasında bir araç olarak dramaya ilişkin en az yapısal ve fonksiyonel analojiler geliştirdikleri görülmektedir.

Öğretmen adayları sosyal girişimcilik becerilerinin kazandırılmasında bir araç olarak yaratıcı drama kavramına sunum şekline göre tamamının sözel analoji olacak şekilde analojiler geliştirdikleri görülmektedir. Sözel analojilerde hedef kavram ve kaynak arasındaki benzerlik sadece kelimeler kullanılarak gerçekleştirilir. Bunun yanı sıra öğretmen adayları kaynak ve hedefin soyutlama düzeyine göre 5 soyut-soyut analoji, 12 somut-soyut analoji geliştirmiştir. 
Araştırmada hedef kavram soyut bir kavramdır. Bu nedenle araştırmada tek bir hedef kavram olduğu ve onun da soyut bir kavram olduğundan dolayı geliştirilen analojiler somut-somut analojiler sinıflandırmasında yer almamaktadır. Ayrıca öğretmen adayları zenginlik düzeyine göre 6 basit analoji, 4 zenginleştirilmiş analoji, 3 genişletilmiş analoji geliştirmiştir. Araştırmada hedef kavram ve kaynak arasında gerekçe ve sinırlılık belirtilmeyen basit analojilerin, hedef kavramı açıklamak için birden fazla kaynak kullanılan zenginleştirilmiş analojilerden ve gerekçe ile sınırlılıkları belirtilmiş olan genişletilmiş analojilerden daha fazla sayıda olduğu görülmektedir.

Öğretmen adaylarının geliştirdikleri analojilerin analoji sınıflandırmalarındaki doğrudan alıntıları şu şekildedir:

"Sosyal girişimcilik becerilerinin kazandırılmasında drama bir araç olarak köprüye benzer. Köprüye yönelik benzer yönler; hedefe ulaşmayı sağlaması, hayatı kolaylaştırması, zamanı iyi kullanmayı sağlaması, zorlukların üstesinden gelinmesini sağlaması olarak belirtilmiştir. Köprüye yönelik farklı yönler; her köprünün her zaman doğru amaca ulaştırmaması, köprülerin yıpranmış olması zamandan tasarrufu sağlarken yıpratıcı olması şeklinde belirtilmiştir." (ÖA $\left.\mathrm{O}_{21}\right)$ Öğretmen adayının ifadeleri incelendiğinde hem şekil, görünüş ve büyüklük hem de görev, hareket ve davranış gibi özellikler yönünden yapısal ve fonksiyonel analoji olarak ele alındığı görülmektedir.

"Sosyal girişimcilik becerilerinin kazandırılmasında drama bir araç olarak ipe benzer. İpe yönelik benzer yönler; inanları bir amaç için bir araya toplaması, güçlü bir bağ oluşturması, farklı renklerde, maddelerde yapılsa da bir araya getirme özelliğinin olması olarak belirtilmiştir. İpe yönelik farklı yönler; her zaman doğru şekilde birleştirici özelliğinin olmaması, kopunca bölünmenin ve güçsüzleşmesinin etkisinin daha farklı olması şeklinde belirtilmiştir." (ÖA $\left.\mathrm{O}_{5}\right)$ Burada hedef kavram hem şekil, görünüş ve büyüklük hem de görev, hareket ve davranış gibi özellikler yönünden yapısal ve fonksiyonel analoji olarak ele alındığı görülmektedir.

"Sosyal girişimcilik becerilerinin kazandırılmasında drama bir araç olarak hayata benzer. Hayata yönelik benzer yönler; farkındalığı sağlaması, deneyimleri içinde barındırması olarak belirtilmiştir. Hayata yönelik farklı yönler; canlandırmaların günlük hayattan farklı olması, hayat içinde öngörülemeyen daha fazla değişkenin olması şeklinde belirtilmiştir." (ÖA ${ }_{45}$ ) Burada hedef kavram görev, hareket ve davranış gibi benzer özellikler yönünden fonksiyonel analoji olarak ele alınmıştır.

"Sosyal girişimcilik becerilerinin kazandırılmasında drama bir araç olarak lunaparka benzer. Lunaparka yönelik benzer yönler; uygulamalı olması, eğlenceli olması, keyifli zaman geçirilmesi olarak belirtilmiştir. Lunaparka yönelik farklı 
yönler; tehlikeli olması, her yaştaki birey için uygun olmaması, risk almanın bir sınırının olması şeklinde belirtilmiştir." (ÖA67) Burada hedef kavram soyut, kaynak somut durumda olduğundan somut-soyut analojiler olarak ele alınmıştır.

"Sosyal girişimcilik becerilerinin kazandırılmasında drama bir araç olarak özgürlüğe benzer. Özgürlüğe yönelik benzer yönler; bireylerin kendilerini rahat hissetmeleri olarak belirtilmiştir. Özgürlüğe yönelik farklı yönler; aktifliğin, rahat olmanın bir başka insanın özgürlük sınırını ihlal edebilmesi olarak belirtilmiştir." $\left(\mathrm{Ö}_{54}\right)$ Burada hedef kavram ve kaynak soyut durumda olduğundan soyut-soyut analojiler olarak ele alınmıştır.

"Sosyal girişimcilik becerilerinin kazandırılmasında drama bir araç olarak evin temeline benzer. Ev temeline yönelik benzer yönler; hayatın temeli olması olarak belirtilmiştir. Ev temeline yönelik farklı yönler; evin yıkılmaz olmasında yeterli olmaması olarak belirtilmiştir." (ÖA $\mathrm{O}_{22}$ ) Burada hedef kavram ve kaynak arasında gerekçe ve sınırlılık belirtilmediğinden basit analoji olarak ele alınmıştır.

"Sosyal girişimcilik becerilerinin kazandırılmasında drama bir araç olarak bisiklet sürmeye benzer. Bisiklet sürmeye yönelik benzer yönler; erken yaşlarda tanışma, hareket becerisi kazandırma, denge de durmayı, uyumla pedalları çevirirken eşgüdümlü hareket etmeyi sağlama olarak belirtilmiştir. Bisiklet sürmeye yönelik farklı yönler; aşamalar halinde öğrenilmesi, bireysel özelliklerine göre (fiziksel duruş, kas, psikomotor motor beceriler)kullanım becerisinde farklılık göstermesi olarak belirtilmiştir." (ÖA $\left.{ }_{36}\right)$ Burada hedef kavram ve kaynak arasında gerekçe ve sınırlılık belirtildiğinden zenginleştirilmiş analoji olarak ele alınmıştır.

\section{TARTIŞMA, SONUÇ ve ÖNERILER}

$\mathrm{Bu}$ bölümde öğretmen adaylarının geliştirmiş olduğu analojiler yapı ve çeşitlerine göre sınıflandırılmış, ilgili alan yazın incelenerek tartışılmıştır.

Kaynak ve hedef unsurları arasındaki ilişkiye göre incelendiğinde, öğretmen adaylarının geliştirdiği analojilerin yapısal olanlarının sayısı; ilişkilerine göre diğer analoji türlerinden daha fazladır. Fonksiyonel olanların ve hem yapısal hem de fonksiyonel olanların analojilerin sayısından fazla olduğu belirlenmiştir. Öğretmen adayları hedef kavram olan sosyal girişimciliği ilişkilendirmede yaratıcı dramanın bir araç olarak kullanımını fiziksel görünüm ya da oluşum açısından yapısal analojilerle; işlevsel olarak ise fonksiyonel analojilerle ortaya koymuşlardır. Nottis ve McFarland (2001) ve Karadeniz (2017) araştırmalarında öğretim sürecinde öğrenme faaliyetlerinin geliştirilmesi için ağırlıklı olarak yapısal analojilerin kullanıldığını ortaya koymuşlardır. Daha karmaşık ve soyut kavramların öğretiminde ise daha çok fonksiyonel analojiler tercih edilmektedir (Curtis ve Reigeluth, 1984). Bu araştırmada adayların daha çok yapısal 
analojilere yer vermesi sosyal girişimcilik becerilerinin kazandırılmasında yaratıcı dramanın rolünün tam anlamıyla anlaşılmadığını düşündürebilir. Bununla birlikte bu araştırmada öğretmen adayları yapısal ve fonksiyonel analojilere daha az yer verdikleri ortaya konmuştur. Sosyal girişimcilik kavramı çok sayıda faktörün belli koşullarda bir araya gelmesiyle oluşur (İlhan, 2003). Alan yazında bilgilerin daha anlamlı hale gelmesi ve edinilen bilgilerin zihinde daha uzun süre kalabilmesi için analojilerin hem yapısal hem de fonksiyonel olması önerilmektedir (Thiele ve Treagust, 1994). Araştırmadan elde edilen sonuç çerçevesinde öğretmen adaylarının az sayıda yapısal ve fonksiyonel analojiler üretmeleri, adayların sosyal girişimciliğin çok boyutlu yapısını tam olarak kavrayamadıklarını düşündürmektedir.

Araştırma bulguları sunum formatı açısından incelendiğinde, öğretmen adaylarının sosyal girişimcilik becerilerinin kazandırılmasında bir araç olarak yaratıcı drama kavramına ilişkin analojilerinin tamamının sözel analojiler olduğu belirlenmiştir. Sözel analojilerde hedef kavram ve kaynak arasındaki benzerlik sadece kelimeler kullanılarak gerçekleştirilir. Kaya ve Durmuş (2011) araştırmalarında öğretmen adaylarının geliştirdikleri analojilerin sözel analojiler olduğunu vurgulamışlardır. Ertirel (2019) ise öğretim sürecinde geliştirilen analojilerin daha çok sözel analojiler olduğunu ortaya koymuştur. Adayların bu araştırmada sadece sözel analojilere yer vermesi, sosyal girişimcilik becerilerinin kazandırılmasında yaratıcı dramanın rolüne ilişkin bilgilerinin daha yüzeysel kaldığını düşündürmektedir.

Kaynak ve hedef arasındaki unsurların durumuna göre incelendiğinde, öğretmen adaylarının geliştirdikleri analojilerin ağılıklı olarak somut-soyut analojiler olduğu görülmektedir. Hıdır ve Didiş Körhasan (2018) çalışmalarında öğretim sürecinde soyut olayları somutlaştıran analojilere sıklıkla yer verildiğini ifade etmişlerdir. Benzer şekilde Digilli (2014) çalışmasında öğretmen adaylarının tamamına yakınının somut-soyut analojiler tasarladıklarını ortaya koymuştur. $\mathrm{Bu}$ araştırmada ise öğretmen adaylarından soyut olan sosyal girişimcilik kavramını yine soyut olan yaratıcı drama kavramıyla ilişkilendirerek analojiler geliştirmeleri beklenmiştir. Dolayısıyla analojik anlamda algıları her iki kavramın öğretiminde de soyut kavramların somutlaştırılması yönünde olmuştur. Bununla birlikte araştırmada adayların soyut-soyut analojilere daha az yer vermesi de her iki soyut kavramın başka bir soyut kavramla ilişkilendirilmesi noktasında sorun yaşadıklarını düşündürebilir.

Araştırmada geliştirilen analojiler zenginlik düzeylerine göre incelendiğinde, öğretmen adaylarının diğerlerine oranla basit analojileri sayıca fazla geliştirdikleri görülmektedir. Öğretmen adayları hedef kavram olan sosyal girişimcilik ile kurulan benzerlikte sınırlılıkları ve gerekçeleri belirtmedikleri belirlenmiştir. Demirci Güler ve Yağbasan (2008) araştırmalarında öğretim 
sürecinde daha çok basit analojilerin kullanıldığını ortaya koymuştur. Analojilerin yeterince anlaşılabilir olması için, oluşturulurken bilinmeyen ile bilinen kavramlar arası yeterli benzerlik kurulması, sınırlılıklarının açıklanması, sonuç ifadelerinin de açık ve net olması beklenir (Orgill ve Bodner, 2006). Bu araştırmada adayların daha çok basit analojilere yer vermelerinin nedeni soyut bir kavram olan sosyal girişimciliği aktif bir yöntem olan yaratıcı dramayla ilişkilendirme noktasında adayların zorlandıklarını düşündürmektedir.

Araştırmada elde edilen sonuçlara dayalı olarak şu öneriler getirilebilir:

- Sosyal girişimcilik gibi çok yönlü faktörlerden etkilenen soyut kavramların öğretimi noktasında yaratıcı drama gibi etkileşimli tekniklerin kullanımı yaygınlaştırılabilir.

- Farklı karmaşık kavramların öğretiminde tüm sınıflama biçimlerinde analojilerin arttırılmasına yönelik analojilerin kullanılması ile farkındalık çalışmaları yapılabilir.

- Hizmet öncesinde öğretmen adaylarının sosyal girişimcilik konusunda donanımlı yetiştirilmesi için öğretmen adaylarına sosyal girişimcilik ile ilgili uygulamalı eğitimler verilerek farkındalık oluşturulabilir.

- Sosyal girişimcilik becerilerinin kazandırılmasına yönelik öğretmenler için uygulama kitapçıkları geliştirilebilir.

\section{KAYNAKLAR}

Akar, Muhammed Said (2007), Laboratuvar Dersinde Yazma Metinleri Oluşturmanın ve Analoji Kullanımının Akademik Başarıya Etkisi, Yayımlanmamış Yüksek Lisans Tezi, Atatürk Üniversitesi, Fen Bilimleri Enstitüsü, Erzurum.

Akpınar, Selma (2009), Girişimciliğin Temel Bilgileri, Umuttepe Yayınları, Kocaeli.

Atav, Esin; Erdem, Emine; Y1lmaz, Ayhan ve Gücüm, Berna. (2004), "Enzimler Konusunun Anlamlı Öğrenilmesinde Analojiler Oluşturmanın Etkisi”, Hacettepe Üniversitesi Eğitim Fakültesi Dergisi, 27, ss. 21-29.

Bal İncebacak, Belgin; Sarışan Tungaç, Aslı ve Yaman, Süleyman (2017), "Yaratıcı Drama ile Öğretim Uygulamasına Yönelik Öğrenci Görüşleri”, Amasya Üniversitesi Eğitim Fakültesi Dergisi, 6(1), ss. 214248. 
Besler, Senem (2010), Sosyal Girişimcilik, S. Besler (Ed.), Sosyal Girişimcilik içinde (ss. 3-28), Beta Yayınları, İstanbul.

Best, John ve Kahn, James (2017), Eğitimde Araştırma Yöntemleri, M. Durmuşçelebi (Çev.), O. Köksal (Çev. Ed.), Dizgi Ofset, Konya.

Biçer, Baykal ve Başer, Enis Harun (2019), “Öğretmen Adaylarının Empatik Eğilimlerinin Sosyal Girişimcilik Özelliklerini Yordama Gücü ve Empatik Eğilim ile Sosyal Girişimcilik Özelliklerini Etkileyen Faktörler", Anemon Muş Alparslan Üniversitesi Sosyal Bilimler Dergisi, 7(5), ss. 235-243.

Çalışkan, Erkan (2019), “Öğretmen Adaylarının Sosyal Girişimcilik Özellikleri ile Sosyal Problem Çözme Becerileri Arasındaki îlişsinin İncelenmesi”, Fen, Matematik, Girişimcilik ve Teknoloji Eğitimi Dergisi, 2(2), ss. 93-114.

Curtis, Ruth ve Reigeluth, Charles (1984), "The Use of Analogies in Written Text”, Instructional Science, 13, ss. 99-117.

Çermik, Fatih ve Şahin, İbrahim Fevzi (2015), "Sosyal Bilgiler Öğretmeni Adaylarının Sosyal Girişimcilik Özelliklerinin Çeşitli Değiş̧kenler Açısından İncelenmesi”, Current Research in Education, 1(2), ss. 76-88.

Demirci Güler, Pınar ve Yağbasan, Rahmi (2008), "Fen ve Teknoloji Ders Kitaplarında Kullanılan Analojilerin ve Analojilere İlişkin Sorunların Betimlenmesi”, İnönü Üniversitesi Eğitim Fakültesi Dergisi, 9(16), ss. 105-122.

Digilli, Azize (2014), Fen Bilgisi Öğretmen Adaylarının Geliştirdikleri Benzeşimler (Analojiler) Üzerine Bir Araştırma, Yayınlanmamış Yüksek Lisans Tezi, Necmettin Erbakan Üniversitesi, Eğitim Bilimleri Enstitüsü, Konya.

Eraslan, Levent (2011), “İköğretim Programlarında Girişimcilik Öğretimi (Hayat Bilgisi Dersi Örneği)”, Gazi Üniversitesi Endüstriyel Sanatlar Eğitim Fakültesi Dergisi, 27, ss. 82-94.

Ertirel, Talat (2019), Ortaöğretim 9. ve 10. Sınıf Kimya Ders Kitaplarında Kullanılan Analojilerin İncelenmesi, Yayınlanmamış Yüksek Lisans Tezi, Gazi Üniversitesi, Eğitim Bilimleri Enstitüsü, Ankara.

Gusseinova, Dilara (2015), Sosyal Girişimcilik Olgusu ve Bir Örnek Olay İncelemesi, Yayınlanmamış Yüksek Lisans Tezi, Dokuz Eylül Üniversitesi, Sosyal Bilimler Enstitüsü, İzmir. 
Güler, Bekir (2014), Çeşitli Öğretim Teknikleri Analoji (Metafor) Tekniği. F. Güneş (Ed.), Öğretim ilke ve yöntemleri içinde (ss. 378-380), Pegem Akademi, Ankara.

Hıdır, Mustafa ve Didiş Körhasan, Nilüfer (2018), "Fen Ders Kitaplarındaki Analojilerin İncelenmesi ve Fen Öğreticilerinin Analojilerin Etkin Kullanımına İlişkin Görüsşleri”, Necatibey Eğitim Fakültesi Elektronik Fen ve Matematik Eğitimi Dergisi, 12(2), ss. 415-453.

İlhan, Süleyman (2003), "Sosyo-Ekonomik Bir Fenomen Olarak Girişimciliğin Oluşumunu Etkileyen Başlıca Faktörler”, Muğla Üniversitesi Sosyal Bilimler Enstitüsü Dergisi, 11, ss. 61-79.

Kadayıfçı, Hakkı (2008), Yaratıcı Düşünmeye Dayalı Öğretim Modelinin Öğrencilerin Maddelerinin Ayrılması ile İlgili Kavramları Anlamalarına ve Bilimsel Yaratıcılıklarına Etkisi, Doktora Tezi, Gazi Üniversitesi, Eğitim Bilimleri Enstitüsü, Ankara.

Karademir, Ersin; Balbağ, Mustafa Zafer ve Çemrek, Fatih (2018), “Öğretmen Adaylarının Girişimcilik Düzeylerinin Bazı Değişkenlere Göre İncelenmesi”, Millî Eğitim, 220, ss. 177-200.

Karadeniz, Serkan (2017), Ortaokul Matematik Ders Kitaplarında Kullanılan Analojilerin İncelenmesi, Yayınlanmamış Yüksek Lisans Tezi, Kastamonu Üniversitesi, Fen Bilimleri Enstitüsü, Kastamonu.

Katzenstein, James ve Chrispin, Barbara R. (2011), "Social Entrepreneurship and a New Model for International Development in the 21st Century", Journal of Developmental Entrepreneurship, 16(1), ss. 87-102.

Kaya, Emine (2010), Fen ve Teknoloji Ders Kitaplarında ve Öğretim Programındaki Benzetmelerin Gruplandırılması, Yayınlanmamış Yüksek Lisans Tezi, Karadeniz Teknik Üniversitesi, Eğitim Bilimleri Enstitüsü, Trabzon.

Kaya, Sinan ve Durmuş, Alpaslan (2011), "Bilişim Teknolojileri Öğretimi İçin Geliştirilen Örnek Analojilerin İncelenmesi”, Journal of Kırşehir Education Faculty, 12(2), ss. 235-254.

Kickul, Jill ve Lyons, Tohamas S. (2012), Understanding Social Entrepreneurship: The Relentless Pursuit of Mission in an Ever Changing World, Routledge Publishing, New York.

Konakl1, Tuğba ve Göğüş, Nur (2013), “Aday Öğretmenlerin Sosyal Girişimcilik Özellikleri Ölçeği: Geçerlik ve Güvenirlik Çalışması”, 
Gazi University Journal of Gazi Educational Faculty (GUJGEF), 33(2), ss. 373-391.

Kümbül Güler, Burcu (2008), Sosyal Girișimciliği Etkileyen Faktörlerin Analizi, Doktora Tezi, Dokuz Eylül Üniversitesi, Sosyal Bilimler Enstitüsü, İzmir.

Lincoln, Yvonna S. ve Guba, Egon G. (1986), "But is it Rigorous? Trustworthiness and Authenticity in Naturalistic Evaluation”, New Directions for Evaluation, 30, ss.73-84.

McCaslin, Nellie (2016), Yaratıcı Drama: Sınıf İçinde ve Dışında. (Çev. Ed. Pınar Özdemir Şimşek), 8. Baskı, Nobel Akademik Yayıncılık, Ankara.

McMillan, James McMillan ve Schumacher, Sally (2014), Research in Education: Evidence-Based İnquiry (7th Edition), Pearson, Boston.

Merriam, Sharan B. ve Tisdell, Elizabeth J. (2015), Qualitative Research: A Guide to Design and Implementation (4th Edition), Jossey Bass, San Fransisco.

Merriam, Saharan B. (2013), Nitel Araştırma: Desen ve Uygulama için Bir Rehber (3. Baskıdan Çeviri) S. Turan (Çev. Ed.), Nobel Yayın Dağıtım, Ankara.

Miles, Matthew B. ve Huberman, A. Michael (2015), Nitel Veri Analizi: Genişletilmiş Bir Kaynak Kitap (1. Baskı), S. Akbaba Altun ve A. Ersoy (Çev. Eds), Pegem Akademi, Ankara.

Millî Eğitim Bakanlığı [MEB] Öğretmen Yetiştirme ve Geliştirme Genel Müdürlüğü, (2017). Öğretmenlik Mesleği Genel Yeterlilikleri (Erişim: 24.06.2019),http://oygm.meb.gov.tr/meb_iys_dosyalar/2017_12/0617244 1 Ygretmenlik Meslegi Genel Yeterlikleri.pdf

Neuman, William Lawrence ve Robson, Colin (2014), Basics of Social Research, Pearson, Toronto.

Newton, Lynn D. (2003), “The occurrence of Analogies in Elementary School Science Books”, Instructional Science, 31, ss. 353-375.

Nottis, Katharyn Ellen Ketter ve Mc Farland, Jacqueline (2001), “A comparative analysis of pre-service teacher analogies generated for process and structure concepts”, Electronic Journal for Research in Science and Mathematics Education, 5, 4. 
Oğuz, Ayşegül (2019), Drama, T. Erdoğan (Ed.), Drama içinde (ss. 1-17), Eğiten Kitap, Ankara.

Orgill, Marykay ve Bodner, George (2006), “An Analysis of the Effectiveness of Analogy Use in College-Level Biochemistry Textbooks”, Journal of Research in Science Teaching, 43(10), ss. 1040-1060.

Önder, Alev (2003), Okul Öncesi Çocuklar için Eğitici Drama Uygulamaları, Morpa Yayınları, İstanbul.

Özdevecioğlu, Mahmut ve Cingöz, Ayşe (2009), "Sosyal Girişimcilik ve Sosyal Girişimciler: Teorik Çerçeve", Erciyes Üniversitesi İktisadi ve İdari Bilimler Fakültesi Dergisi, 32, ss. 81-95.

Paksoy, Mustafa; Özbezek, Dilek ve Gül, Meryem (2019), “Kişilik Özellikleri ve Sosyal Sorumluluk Bilincinin Sosyal Girişimcilik Özelliklerine Etkileri Üzerine Bir Araştırma”, Social Sciences, 14(3), ss. 973-1006.

Schreglmann, Sinan (2019), “Ortaöğretim Bilgisayar Bilimi Ders Kitabındaki Analojilerin İncelenmesi”, Elementary Education Online, 18(4), ss. 1641-1651.

Stake, Robert (2005), Case Studies, N. K. Denzin ve Y. S. Lincoln (Eds.), in The SAGE Handbook of Qualitative Research (Third Edition). London: Sage.

Thiele, Rodney ve Treagust, David (1994), “The Nature and Extend of Analogies in Secondary Chemistry Textbooks”, Instructional Science, 22, ss. 61-74.

Ünver, Gülsen; Bümen, Nilay ve Başbay, Makbule (2010), “Ortaöğretim Alan Öğretmenliği Tezsiz Yüksek Lisans Derslerine Öğretim Elemanı Bakışı: Ege Üniversitesi Örneği”, Eğitim ve Bilim, 35(155), ss. 63-77.

Yenice, Nilgün; Alpak Tunç, Gizem ve Yavaşoğlu, Neslihan (2018), "Ortaöğretim Öğrencileri ile Fen Bilgisi Öğretmen Adaylarının Biyoloji Kavramına İlişkin Geliştirdikleri Analojiler”, Muğla Sitkı Koçman Üniversitesi Eğitim Fakültesi Dergisi, 5(2), ss. 16-30.

Yerrick, Randy; Doster, Elizabeth; Nugent, Jeffrey; Parke, Helen ve Crawley, Frank (2003), "Social Interaction and the Use of Analogy: An Analysis of Preservice Teachers’ Talk During Physics Inquiry Lessons”, Journal of Research in Science Teaching, 40(5), ss. 443-463.

Yıldırım, Ali ve Şimşek, Hasan (2011), Sosyal Bilimlerde Nitel Araştırma Yöntemleri, (8. Baskı), Seçkin Yayınları, Ankara. 
Yin, Robert (2003), Case Study Research Design and Methods (3. Bask1), Sage Publications, London.

Yüksek Öğretim Kurulu [YÖK] Yeni Öğretmen Yetiştirme Lisans Programları, (2018). (Erişim: 24.06.2019), https://www.yok.gov.tr/kurumsal/idari-birimler/egitim-ogretimdairesi/yeni-ogretmen-yetistirme-lisans-programlari

Zibeniene, Gintaute ve Virbaliene, Rita (2014), “Learning Methods of Entrepreneurship Education”, Education reform in comprehensive school, ss. 123-133. 